\title{
David Oliver: Handling complaints with realism and fairness to staff
}

\author{
David Oliver consultant in geriatrics and acute general medicine
}

Berkshire

From the launch of Channel 4 television in 1982, a programme called Right to Reply was a regular feature: viewers phoned, wrote, or used video booths to praise or complain about programmes. Bosses and programme makers appeared too, to put their side of the story.

Continuing this tradition, Channel 4 has launched a "Complaints Welcome" campaign encouraging viewers to complain, but with adverts openly posting some of the more abusive or dubious comments received. ${ }^{1}$ Might this offer a shining example to the NHS?

Watching television isn't as personal or fraught as using health services when you're scared and ill. I'm not proposing gentle ridicule of complainants, as employed in Channel 4's campaign. But we may have something to learn from it in encouraging feedback and in the open, robust response to it.

Endless reports show how people, harmed or distressed by poor communication, medical error, or care failings, have had this compounded by how complaints are handled. Too many people face bureaucratic, lengthy, defensive responses—and, in the worst cases, attempts to hide the truth. In other cases people believe that the Patient Advice and Liaison Service or legal action is the only way they can get sense from the system.

I'm not here to defend the indefensible. I'd argue that we could prevent many complaints from occurring at all or could stop them from escalating by communicating proactively, sensitively, and openly. We should make ourselves readily available to do so. Access to mediation and early independent review might also help. ${ }^{2}$

On the other hand, I don't think that the NHS is short on feedback when compared with other sectors. As well as the formal complaints system ${ }^{3}$ and ombudsman, we have litigation, coroners' inquests, a system of incident reporting and investigation, staff annual appraisal, patient surveys, friends and family tests, a whole regime of performance targets, media and political scrutiny, and unchallenged public comments on websites. ${ }^{4}$ Professional rules around patient confidentiality ${ }^{56}$ mean that clinical staff can't easily push back, combat misinformation, or defend their reputations. This can be stressful, not least when stories hit the mainstream media and staff have to watch mistruths being repeated with no right of redress.

Even if formal complaints do stem from poor communication or misunderstandings, some are factually wrong on numerous points. Others are personal, discriminatory, even abusive. The fact that patients and families are in distressing and unfamiliar environments, with a structural power and knowledge imbalance, doesn't justify all behaviour. If we're serious about staff wellbeing and morale we must protect, defend, and support them.

And if we're serious about candour, transparency, and openness, let's start answering complaints with honesty about constraints and pressures on the system-and what now constitutes realistic expectations. If people want the truth we should give it to them. Let's tell it as it is about the number of people coming through emergency departments, the daily struggle for beds, and the number of other patients and families in equal need. Let's be honest about the failure to invest in building and equipment, the endemic staffing gaps, and the efforts individual trusts have made to solve them.

Let's discuss attacks on social care funding and the lack of capacity in community health services, which leads to stranded patients. ${ }^{7}$ Let's highlight that these are endemic, systemwide, structural problems resulting from national policy and not unique to any organisation. Let's admit that long waiting times, overcrowding, process delays, rushed care, and insufficient time to give regular updates are sometimes a fact of modern NHS life.

Of course, we should apologise early and unequivocally when we've got things wrong and should use complaints as an opportunity to learn. Often, families highlight problems we'd do well to heed and act on for the benefit of future patients. But welcoming complaints and feedback, and answering them candidly, shouldn't stop us doing so with unvarnished honesty, realism, and fairness to the clinical staff and operational managers who are doing their best in trying circumstances. 
Competing interests: See bmj.com/about-bmj/freelance-contributors.

Provenance and peer review: Commissioned; not externally peer reviewed.

Channel 4. "Complaints Welcome" video. https://www.channel4.com/press/news/channel4-talent-campaign-showcases-genuine-viewer-complaints.

2 Doctor urges compulsory mediation in patient care rows. BBC News 2016 May 29. https: //www.bbc.co.uk/news/health-36407596.

3 NHS. How to complain to the NHS. https://www.nhs.uk/using-the-nhs/about-the-nhs/howto-complain-to-the-nhs/.

4 Ripullone K, Womersley K. What we don't talk about when we talk about professionalism: Feedback. BMJ Opinion 2019 Oct 24. https://blogs.bmj.com/bmj/2019/10/24/what-wedont-talk-about-when-we-talk-about-professionalism-feedback/.
5 General Medical Council. The duties of a doctor registered with the General Medical Council. https://www.gmc-uk.org/ethical-guidance/ethical-guidance-for-doctors/goodmedical-practice/duties-of-a-doctor.

6 General Medical Council. Doctors' use of social media. https://www.gmc-uk.org/ethicalguidance/ethical-guidance-for-doctors/doctors-use-of-social-media. 22 Apr 2013.

7 National Audit Office. Report on discharge from hospital. https://www.nao.org.uk/report/ discharging-older-patients-from-hospital/.

Published by the BMJ Publishing Group Limited. For permission to use (where not already granted under a licence) please go to http://group.bmj.com/group/rights-licensing/ permissions 